\title{
Integrating Science, Technology, Engineering and Mathematics contents through PBL in an lndustrial Engineering and Management first year program
}

\author{
Anabela Carvalho Alves ${ }^{\mathrm{a*}}$ (D), Francisco Moreira ${ }^{\mathrm{a}}$ (D), Maria Alice Carvalho ${ }^{\mathrm{a}}$ (D), Sérgio Oliveira ${ }^{\mathrm{a}}$, \\ Maria Teresa Malheiro ${ }^{\mathrm{a}}$ (D), Irene Brito ${ }^{\mathrm{a}}$ (D), Celina Pinto Leão ${ }^{\mathrm{a}}$ (D), Senhorinha Teixeira ${ }^{\mathrm{a}}$ (D) \\ aUniversidade do Minho, Guimarães, Portugal \\ *anabela@dps.uminho.pt
}

\begin{abstract}
Paper aims: This paper presents teachers and students perspectives of integration Science, Technology, Engineering and Mathematics (STEM) courses contents into the first year of Industrial Engineering and Management (IEM) program through Project-Based Learning (PBL).

Originality: These perspectives provide strategies that IEM teachers could use to challenge students to apply STEM contents to design a product and its production system by developing a semester interdisciplinary project.

Research method: Grounded on project deliveries and an on-line questionnaire, the teachers and students' work and perceptions were analysed in order to understand and to evaluate the effectiveness of such strategies.

Main findings: Results pointed out a general satisfaction of the teachers with the way teams integrate the STEM contents to design the production system and the product and students proud of their projects.

Implications for theory and practice: PBL is recognized as an active learning methodology that engages students in their own learning process and allows them to realize the relevance of all courses and the role of each to design a product/production system. Nevertheless, is fundamental a good knowledge of the PBL process to achieve this.
\end{abstract}

Keywords

STEM. PBL. Active and student-centred learning methodologies. Industrial engineering and management.

How to cite this article: Alves, A. C., Moreira, F., Carvalho, M. A., Oliveira, S., Malheiro, M. T., Brito, 1., Leão, C. P., \& Teixeira, S. (2019). Integrating Science, Technology, Engineering and Mathematics contents through PBL in an Industrial Engineering and Management first year program. Production, 29, e20180111. https://doi.org/10.1590/0103-6513.20180111

Received: Jan. 21, 2018; Accepted: May 13, 2019.

\section{Introduction}

The Bologna process (European Commission, 2010) has imposed the need for teachers to adopt new learning methodologies, by making the students more responsible and involved in their own learning process. One of the sixteen recommendations of European Higher Education Institutions (HEI) report (European Commission, 2013) is the need for new methods of teaching and learning (recommendation 7). These recommendations also imply a shift towards a new model of education, focused on acquiring and developing skills by the active involvement of students. According to Bonwell \& Eison (1991) the teachers should promote this model, inside and outside the classroom, emphasizing the active learning (Bonwell \& Eison, 1991). This need of active learning, specifically, project- and problem-based learning (PBL) is also pointed out by a UNESCO report (United Nations Educational, Scientific and Cultural Organization, 2010). 
Anticipating these needs, a team of teachers, from the school of engineering of a public university in Portugal, were impelled to train in active learning methodologies, particularly in Project-Led Engineering Education (PLEE) (Powell \& Weenk, 2003) that is based on PBL. The IEM program has adopted this methodology since the 2004/2005 academic year. PBL has been implemented in the first semester of the first year as an interdisciplinary project, tacked by teams of students and supported by the courses of the semester. Since the 2012/2013 edition, is structured in a formal course unit, holding five ECTS (European Credits Transfer System). This course was designated Integrated Project of Industrial Engineering and Management 1 (IPIEM1), and represents a total workload of 140 hours.

The novel learning process is evaluated and improved yearly, in a continuous action-research cycle (Alves \& Leão, 2015). Along the years, the teachers have done efforts to incorporate further contents of STEM fields in the project. As the project varies each year, the integration of course contents is one of their concerns, given that the students must know how to apply the contents to new situations. The integration challenge was addressed in a prior study (Alves et al., 2016a).

The purpose of the present paper is to describe and evaluate the strategies followed by the teachers' team to incorporate STEM contents in the project. The students' perspectives and evaluation of their learning process are also presented. Different tools were used to evaluate the effectiveness of such strategies: (1) the results of the project reports and other activities performed by the students; (2) an on-line questionnaire about the PBL methodology; and (3) a discussion that followed the final workshop on the project and organized by the coordination team. These provides insights to the strategies taken and applied by each team, the global perspective of the students, and provides a space for a common discussion where both students and teachers share their opinions and believes regarding the project.

This paper is divided in six sections. After this introduction, a brief literature review about student-centred methodologies is presented. Section 3 presents the research methodology and section 4 the context of the study. Section 5 contains the analysis, results and discussion of course contents integration from the teachers' and students' perspectives. Finally, section 6 presents some conclusions.

\section{Integration of STEM in PBL projects}

Active and student-centred learning methodologies are concepts of pedagogical ideas and practices which emphasize the learning process instead of the teaching process (Kolmos, 1996). According to Frank et al. (2003), these methodologies are based on constructivism concepts about learning, in particular, social constructivism theory, whose best-known researcher is Vygotsky (1986). According to these authors, Vygotsky (1986) stated the concepts and meaning construct are learned by learners interacting with others. This is also defended by Kolmos (1996) that viewed the learning as active process of investigation, result of learner interest, curiosity and experience.

PBL is considered one such methodology (Harmer, 2014). Using a project as an educational device started in the sixteenth century with Knoll (1997). At the beginning of the $20^{\text {th }}$ century, the term "project" was redefined, in particular, by William H. Kilpatrick, philosopher of education (Knoll, 1997). And the roots of PBL may be found, not only on Kilpatrick's work but also on Jerome Bruner in the 1960s, and contemporary educators since the 1990s (Frank et al., 2003).

This methodology has been adopted on several educational institutions around the world (Graaff \& Kolmos, 2007; Guerra et al., 2017; Lima et al., 2007, 2017; Powell \& Weenk, 2003). In Higher Education, it is widespread in engineering, where universities in Denmark are the most common example.

Usually, projects in PBL curriculum are developed by small groups of students, where they construct solutions to a given non-trivial problem and communicate their ideas and results to other groups, teachers and tutors. In engineering courses, these projects include Science, Technology, Engineering and Mathematics (STEM) courses.

The term STEM is used to describe the study of those sciences and its links to technology and engineering programs (Bell, 2016). However, it has been used with different educational meanings to different people, producing several forms of implementation (Ritz \& Fan, 2015) and having different level of national priority (Thomas \& Watters, 2015).

On a PBL environment, students could become more aware of real-world and STEM connections, by learning to do something and/or solving problems with STEM knowledge. Using this strategy, they can apply principles, theories and formulas giving them some useful meaning and understand contexts in which they can be applied (Bell, 2016). According to Harmer (2014) PBL advantages includes, among others, skills development related with professional practice. Heywood (2005) considered PBL as a strategy to retain students in universities, 
avoiding their drop-out. Freeman et al. (2014) considered that active learning, like PBL, increases students' performance in STEM.

Laboy-Rush (2011) indicates five phases of a project-based learning process integrating STEM programs: Reflection, Research, Discovery, Application, Communication. There are studies proving that these five stages of STEM project-based learning integration improve students creativity and strengthen students' ability in STEM learning, enhancing their innovation skills (Eguchi, 2016; Lou et al., 2017) and reflecting in the process. Others, namely, LaForce et al. (2017), added that PBL increase students interest by future STEM careers.

On the other way, STEM PBL is also used as an educational strategy to improve students' attitudes towards technology, science and engineering courses as well as their achievements (Capraro et al., 2013; Han et al., 2015; Kezar et al., 2017; Tseng et al., 2013). PBL is an effective way to teach STEM in an integrated and meaningful way (Berry et al., 2012). By developing projects to conceive products such as robots, students are capable of collaborate, program and construct in a team setting (Eguchi, 2016). As so, it has a positive impact in the communication and collaboration skills. This was observed in the Hispanic students in US in classrooms by Han et al. (2016) and in the sustainability concepts learning of Civil Engineering undergraduates students by Fini et al. (2018).

Nevertheless, Laboy-Rush (2011) claimed that there were several challenges to successfully implementing integrated STEM education programs. Such challenges could be overcome with specific attention to the program's design by providing additional preparation time for teachers, additional materials and resources, and the inventory storage. Also, some authors, namely, Stohlmann et al. (2012) called attention to the teachers' role on this, giving suggestions of how to approach student knowledge.

Integration of STEM contents is not a streamline task and in Industrial Engineering programs is reportedly a challenging endeavour (Pereira et al., 2017), giving motivation for the research reported on this paper. The delivery of individual STEM subjects is the traditional way and although the benefits of interdisciplinary collaboration, the attempt at integration is not commonly applied (Bell, 2016). Studies on how to proceed on one such integration are not as common as in other education levels and fields.

\section{Research methodology}

The purpose of this study was to explore and understand how students integrate STEM contents in the project they develop in a PBL context and effectiveness of this integration. This is due attending to teachers and students' perspectives. These perspectives used both quantitative and qualitative data that were collected, analysed and discussed in section 5 (Onwuegbuzie \& Leech, 2006).

Teachers' perspectives were collected through their opinions about project results: reports, presentations, individual written test and prototypes (presented in the fourth chapter). The research questions that guided the authors to reach teachers perspectives were:

- How do students integrate STEM contents in the project?

- Is this integration effective, i.e., do they really understand the role of each course in the project?

The teachers' team that participated in the 2016/2017 edition of the IPIEM1, had six teachers, including the project team coordinator, also a teacher. Two teachers (the coordinator plus another teacher) have knowledge accumulated over many years (more than 10 years) on the use and experience in PBL. Only for one teacher was his first experience and contact with the PBL learning methodology. However, this was a motivating factor, not an impediment. The remaining teachers had a previous experience of about five years. The data collected is of a qualitative nature since it is a result of each teacher's team observation and based on each teacher's notes. This analysis was done by each teacher responsible for each UC so, can vary according to the specific nature of each UC.

Students' perspectives were collected through a questionnaire about the general beliefs regarding PBL methodology as a learning methodology. The research question that drove this research was:

- How do students perceive the integration and the role of the courses contents in the project?

The questionnaire has the advantage of, in a relatively simple and easy way, obtaining data in a short period of time. The questionnaire was made available online for two weeks following the end of the semester. The link of the questionnaire was sent to students by e-mail. Thirty-two students (corresponding to 67\% of the total enrolled students) accepted the challenge and answered the questionnaire in an anonymous form. 
This percentage was considered as a meaningful basis for analysing students' perceptions about PBL as a learning methodology. The questionnaire contains six different sections with 56 closed-ended questions with answers based on the students' level of agreement (from 1: strongly disagree to 5: strongly agree), and three open-ended questions (section seven), which enabled the use of their own words on identifying strengths and weaknesses of this type of project and present improvement proposals. The seven sections cover different aspects regarding the use of PBL, as a learning methodology, and provide an evaluation of the experience. The relevant parts of the questionnaire, just 14 of 56 closed-ended questions, for this research could be found in the section 5.2.

The nature of the data obtained from the questionnaire is quantitative, representing a measurement of the students' level of agreement regarding a set of statements. For the analysis of this data, descriptive statistics and, when relevant, cross-reference to the data obtained was performed. The first analysis summarizes the distribution of students' level of agreement and opinion by estimating measures of central tendency (mean and median) and measures of dispersion (standard deviation, minimum and maximum).

The data obtained in the open-ended questions, presents a qualitative nature that corresponds to a set of words written by students. In this case, a summative qualitative content analysis was done. The words more frequent were identified by the use of specific software (Souza et al., 2016), and, wherever possible, to relate with available literature and student's profile (Hsieh \& Shannon, 2005).

\section{PBL in the Industrial Engineering and Management program}

This section presents the study context of the PBL in the first year of the Industrial Engineering and Management program. It is divided into two parts: 1) description of IPIEM1, highlighting the contribution of all other courses of the semester; and 2) presentation of the learning outcomes of each course, so as to integrate in the IPIEM1, and definition of the tasks to be developed and applied by the students, in the context of each course contents.

\subsection{Integrated Project of Industrial Engineering and Management 1 (IPIEM11)}

The interdisciplinary project of the Integrated Master in Industrial Engineering and Management of the $1^{\text {st }}$ year, $1^{\text {st }}$ semester (IEM 11) is based on PBL, and implies the learning of multidisciplinary contents in engineering. The semester is developed in the form of a large project carried out by teams of students and supported by the teachers of the various Curricular Units (CUs) of the semester (Project Supporting Courses, PSC), namely: 1) Introduction to Industrial Engineering and Management (llEM); 2) General Chemistry (GC); 3) Algorithms and Programing (AP); 4) Calculus (CC); 5) Linear Algebra (LA); and 6) Integrated Project of Industrial Engineering and Management 1 (IPIEM1) (Figure 1).

IIEM, IPIEM 1 and AP belong to the School of Engineering being the IIEM and IPIEM 1 from the Department of Production and Systems and AP from the Department of Information Systems. The other three are from the School of Sciences, being the CC and LA from the Mathematics Department and GC from the Department of Chemistry. Normally, the coordination team could have in average ten members including teachers, tutors and educational researchers.

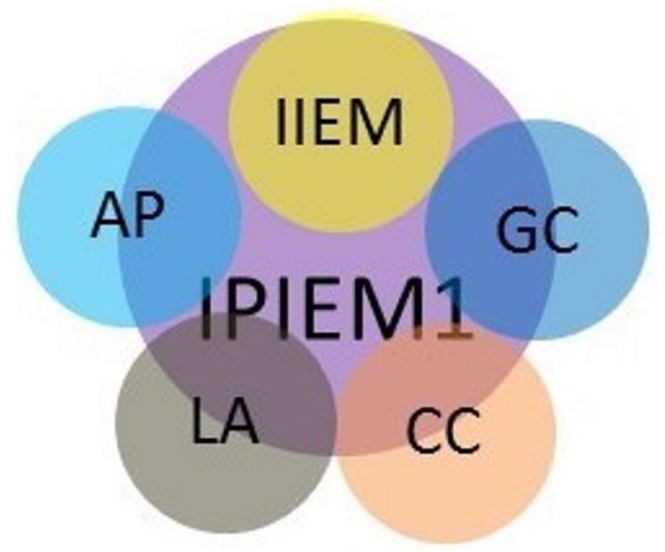

Figure 1. IPIEM1 Project Supporting courses (2016_2017). 
Six teams of students (of 8-9 members) are formed for IPIEM1 and they must demonstrate the acquisition of scientific and technical skills in the project, with the intention of producing solid and eminently practical solutions of products / production systems. By developing these solutions for the project, they also develop other skills essential to the proper exercise of Engineering, namely, teamwork, conflict management, argumentation, written communication, critical evaluation and decision making, while allowing expressions of creativity and initiative, which are fundamental drivers of the processes of innovation and industrial entrepreneurship among others fundamental to IEM graduates (Santos et al., 2017).

IPIEM1 is always organized as a project that goes through all phases of any project: preparation, set-up, start-up, execution and conclusion (Alves et al., 2009; Lima et al., 2012), being the most relevant aspects concerning the PBL implementation at IEM described elsewhere (Alves et al., 2016a, b). Over the fourteen editions (since 2004_05) there was always space for changes in a continuous effort to improve the learning process.

Attending to the main concern of this paper, the description focus is on the integration of the PSCs that, in this edition, are all courses of the first semester, in different proportions. It should be noted that the integration of all courses took some years because it was difficult for some teachers to know how to integrate their contents in the project. More details about this could be found in (Alves et al., 2012).

The role of each course on the production system design is different, as expected. So, it is natural that the contents of each one is proportional to this role and relevance, as Figure 1 above illustrates. For example, llEM is a nuclear course in IEM program, and so, all the contents lectured in the classes are applied in the project development. GC has also a pertinent role, because an important part of the contents is applied in the project. Others, such as CC, LA or AP have a minor role but they are equally important, as will be presented in the following section. Based on this, a schedule plan is prepared for the semester showing teachers' support to the student teams, beyond the classes. IIEM has the highest workload (Alves et al., 2016a, b).

In this particular edition the project was about the "Remanufacture of fashion accessories or footwear made of synthetic material". After a brief description and motivation for the themes under this topic (e.g. sustainable development; linear vs circular economy) it is asked that the teams of the IPIEM1, design one or several products based on materials reused from fashion accessories and/or footwear and design a production system to manufacture these product(s), defining and detailing the processes and solutions found. Then, more details are provided:

1. Specification and identification of the components of the product - identify the product(s) (handbag, belt, etc.) and specify the materials in this product;

2. Specification of the production system for the manufacture of the product - design of the production system.

Also, it was warned that specifications must be rigorous and reasoned according to the competencies defined for each of the curricular units of the semester that are part of the project that are defined in the project guide. Project guide delivered to the students included project description and objectives, coordination team, tutor role, learning outcomes of each course and project, semester plan, weekly schedule, milestones, and assessment model, among other information.

Table 1 presents the milestones with the deliverables of the project and other activities, such as extended tutorial and individual written test. Deliverables of the project included the presentations (pilot, progress and final), reports (preliminary and final) and prototypes of products and production system. During the development of the project, it is expected that students cover the phases described by Laboy-Rush (2011): Reflection, Research, Discovery, Application, Communication.

Table 1. Milestones, deliverables and others activities of the IPIEM1.

\begin{tabular}{cll}
\hline Milestone & Date & \multicolumn{1}{c}{ Deliverables \& others activities } \\
\hline 1 & Week 2 & Pilot project presentation with a blog construction \\
2 & Week 6 & Project progress presentation \\
3 & Week 10 & Extended tutorial \\
4 & Week 13 & Preliminary report (maximum of 50 pages) \\
5 & Week 15 & Final report (maximum of 60 pages) + Prototypes \\
6.1 & Week 16 & Final individual written test \\
6.2 & & Final presentation and discussion \\
\hline
\end{tabular}

Extended tutorial is a student's team meeting with the full coordination team (all teachers at the same time) aiming at monitoring the team progress, in order to discuss common doubts inhibiting them to progress. The individual written test is a global test with contents from the final reports delivered by each team. 1ts main 
objective is to evaluate the knowledge of each team member about the project. It is a tentative to prevent eventual "free-riding" students, and also complement the validity of the peer assessment mechanism. For each team, each teacher prepares a different test according to the team's project report. Normally, this has been a problem as students complain that this test does not reflect their effort and knowledge of the projects. However, students agree with the need of having this kind of assessment mechanism.

The assessment model is quite complex, as it includes several components, encompassing individual and team-based assessment (Figure 2).

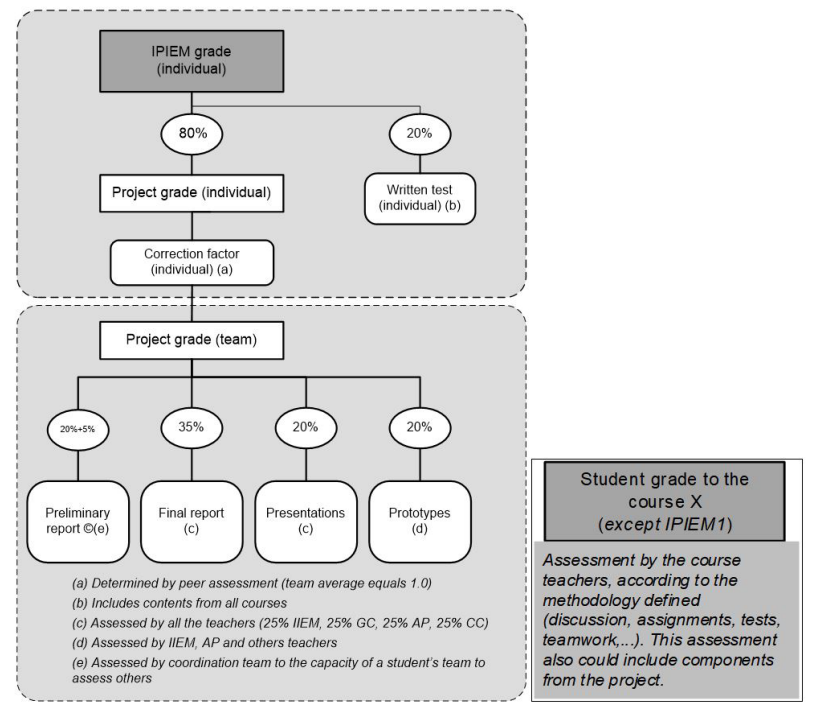

Figure 2. Assessment model of 2016/2017 edition of IPIEM1.

Almost all deliverables are assessed by an average of the grades issued by the courses involved in the IPIEM1. Notes a), b), c), d) and e), included in Figure 2, intend to show who is responsible for the assessment of each component. Production systems and software programs are evaluated by IIEM and AP, respectively. Additionally, products and containers (or others production means) prototypes are not compulsory but can be presented by a team depending on the development and stage of the work. At the end of the semester, depending on the material delivered by each team, teachers are invited to evaluate them. This academic year, IIEM, CC and LA were involved on this evaluation, given that the developed prototypes implied contents from these courses. Also, students deliver others materials, such as flyers advertising their company, badges and videos of the production system simulation.

In this edition, a novelty was introduced that is related with the preliminary report, as the note e) in the Figure 2 intends to show. Project teams were involved in the evaluation of the preliminary report, which was subject to validation by the project coordination team. Each team evaluated a peer report, based on criteria previously defined and negotiated between the coordination team and the students. The evaluation was carried out by one team on another team, and included feedback. The coordination team valued the quality of such evaluation with a maximum of 5\%, which was based in the difference between grade given by the teachers and the grade given by the team (i.e. if the evaluation of the team coincides with the evaluation of the coordination team, the team was awarded a further 5\% in its evaluation of the preliminary report). In this way, each team had an active participation in the reports and a deeper understanding on their own.

\subsection{Learning outcomes and tasks of each course for IPIEM1}

Each course has general learning outcomes, as defined in the courses catalogue and published on the university website. Nevertheless, not all of these are included in the IPIEM1. The contents that students' teams have to include in the project are represented in Figure 3.

This content is yearly adjusted according to the specific project theme. This is the case, for instance, with General Chemistry. Normally, the theme is somehow related with sustainability issues, in order to raise consideration and concern for this issue, and, at the same time, captivate and motivate the students (Alves et al., 2017; Colombo et al., 2014; Moreira et al., 2011). Table 2 presents a list of these project themes throughout the previous editions of PBL in IEM1. 


\begin{tabular}{|c|c|c|c|c|}
\hline IIEM & GC & AP & CC & LA \\
\hline Project Management & $\begin{array}{l}\text { Materials and their } \\
\text { constitution }\end{array}$ & Algorithms & \multirow{2}{*}{$\begin{array}{l}\text { Derivatives of real } \\
\text { functions of one } \\
\text { variable }\end{array}$} & Matrices \\
\hline Team Management & $\begin{array}{l}\text { Materials and their } \\
\text { properties }\end{array}$ & Data structures & & Determinants \\
\hline IE history & Organic compounds & Data persistence & Integrals & \multirow{2}{*}{$\begin{array}{c}\text { Applications of matrices } \\
\text { and determinants to solve } \\
\text { optimization problems }\end{array}$} \\
\hline $\begin{array}{c}\text { PS introduction, } \\
\text { classification and design }\end{array}$ & \multirow[t]{2}{*}{ Chemical equilibrium } & MATLab programming & \multirow{3}{*}{$\begin{array}{c}\text { Applications to } \\
\text { calculate areas of } \\
\text { plane regions, } \\
\text { volumes of revolution } \\
\text { solids and areas of } \\
\text { revolution surfaces }\end{array}$} & \\
\hline $\begin{array}{c}\text { Layout design } \\
\text { Production dynamics }\end{array}$ & & $\begin{array}{c}\text { Functions \& } \\
\text { parameters passing }\end{array}$ & & \multirow{2}{*}{$\begin{array}{c}\text { Systems of linear } \\
\text { equations:Gaussian } \\
\text { elimination; Gauss-Jordan } \\
\text { elimination }\end{array}$} \\
\hline $\begin{array}{c}\begin{array}{c}\text { Key performance } \\
\text { indicators }\end{array} \\
\text { Industrial ecology } \\
\end{array}$ & Entropy and Free Energy & Name spaces & & \\
\hline & & $\checkmark$ & & \\
\hline
\end{tabular}

Figure 3. Contents to include in the project developed in IPIEM1.

Table 2. IPIEM1 multidisciplinary projects: editions and themes.

\begin{tabular}{ll}
\hline Academic Year & \\
\hline $2004 / 2005$ & Production of biodiesel: specify the product and design the production system \\
$2005 / 2006$ & Design of a production system to use forest biomass \\
$2006 / 2007$ & Specification of a fuel cells production system \\
$2007 / 2008$ & Desalination of sea water \\
$2008 / 2009$ & Production of batteries for an electric car: specification of the battery and its production system \\
$2009 / 2010$ & Use of organic waste for the production of bio-alcohol \\
$2010 / 2011$ & Air2Water: specification of a portable device for production of drinking water from air humidity \\
$2011 / 2012$ & Clean-up and recovery of crude oil from sea spills \\
$2012 / 2013$ & Specification of a disassembly line for recycling of waste electrical and electronic equipment (WEEE) \\
$2013 / 2014$ & Design of a more sustainable packaging and specification of the production system \\
$2014 / 2015$ & Reuse of residues of food oils and design of a production system \\
$2015 / 2016$ & Design of solar oven and it production system \\
$2016 / 2017$ & Design a production system to remanufacture fashion accessories or footwear made of synthetic material \\
\hline
\end{tabular}

These contents are taught in classes and then supported in labs or in meetings with the team, in the project rooms. The whole plan is defined at the beginning of the semester (Figure 4). There is an effort to balance the tests and tasks delivery over the semester. In spite of this, the best solution was not always achieved and the students often complain about the hard work required, especially in the busy weeks at semester end.

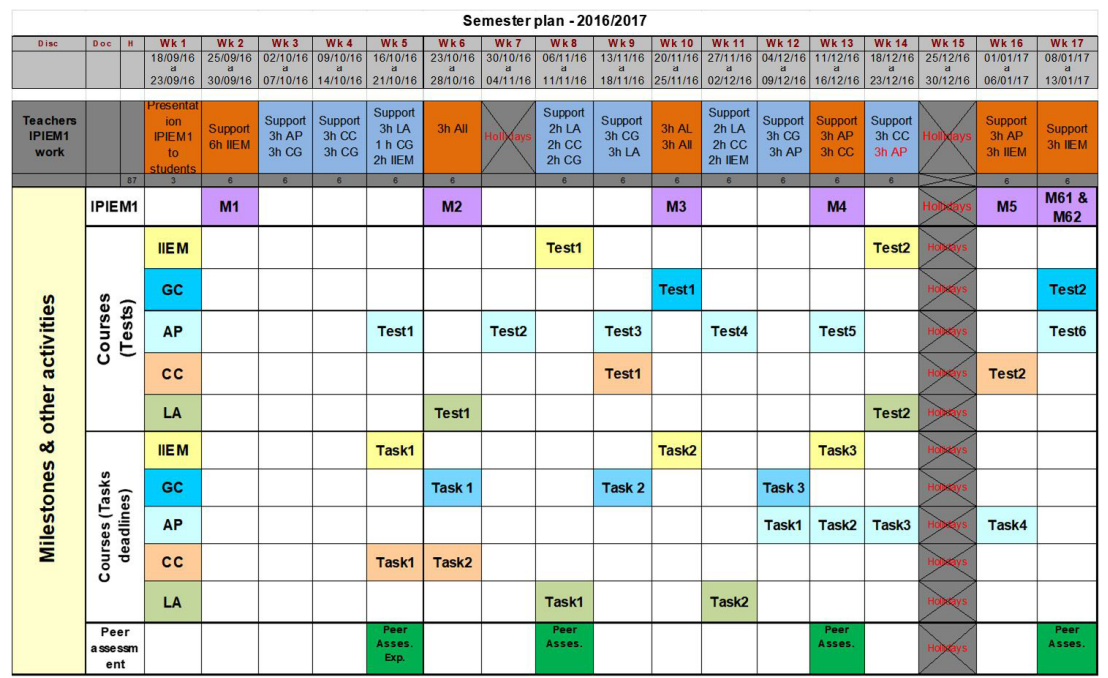

Figure 4. Semester plan with milestones, tests and tasks for IPIEM1. 
Each teacher defined how students should integrate the contents of each course in the project. All the teachers opted to give course-related tasks to the teams. The tasks, after review and evaluation can be used as input material for the deliverables of the project (presentations and reports). Each teacher decided if these tasks are evaluated in the course as components of the evaluation methodology, or if they are tasks required for the IPIEM1 only. Table 3 presents tasks and tests required for each course.

Table 3. Tests and tasks required for courses and/or IPIEM1.

\begin{tabular}{|c|c|c|c|c|c|c|c|c|c|c|}
\hline & \multicolumn{2}{|r|}{ IIEM } & \multicolumn{2}{|r|}{$\mathrm{GC}$} & \multicolumn{2}{|c|}{ AP } & \multicolumn{2}{|c|}{$\mathrm{CC}$} & \multicolumn{2}{|c|}{ LA } \\
\hline & Number & Weight & Number & Weight & Number & Weight & Number & Weight & Number & Weight \\
\hline Tests & 2 & $55 \%$ & 2 & $80 \%$ & 6 & $100 \%$ & 2 & $100 \%$ & 2 & $100 \%$ \\
\hline $\begin{array}{l}\text { Tasks } \\
\text { (in teams) }\end{array}$ & 3 & $\begin{array}{l}45 \% \text { Reviewed, } \\
\text { feedback and } \\
\text { evaluated and } \\
\text { then integrated } \\
\text { in IPIEM1 }\end{array}$ & 3 & $\begin{array}{l}16 \% \\
\text { Reviewed, feedback } \\
\text { and evaluated and } \\
\text { then integrated in } \\
\text { IPIEM } 1\end{array}$ & 4 & $0 \%$ & 2 & $0 \%$ & 2 & $0 \%$ \\
\hline $\begin{array}{l}\text { Other } \\
\text { activities }\end{array}$ & ----- & ----- & & $4 \%$ & ---- & ---- & ---- & ---- & ---- & ---- \\
\hline
\end{tabular}

It is important to say that feedback is given to all tasks, which are graded, and weighed, as shown in Table 3. When each team builds-up the preliminary report, the tasks contents are reviewed and improved, according to the feedback provided, and integrated in the contents of the teams' reports.

The teachers had 15 hours on their timetable to support the students and clarify eventual doubts. The experience showed that it is not enough, it is usual to provide support also at the theoretical-practical classes. In the case of GQ, an extra support of 4 hours was allocated in the edition of this study. Even so, in this course, during theoretical and theoretical-practical classes, the students are constantly requested to solve small problems. Their participation in these activities is evaluated in the continuous assessment component of the course unit. During the semester, the work is continuous, for teachers and students' teams. Figure 5 shows the activities performed by both students and teachers over different project phases.

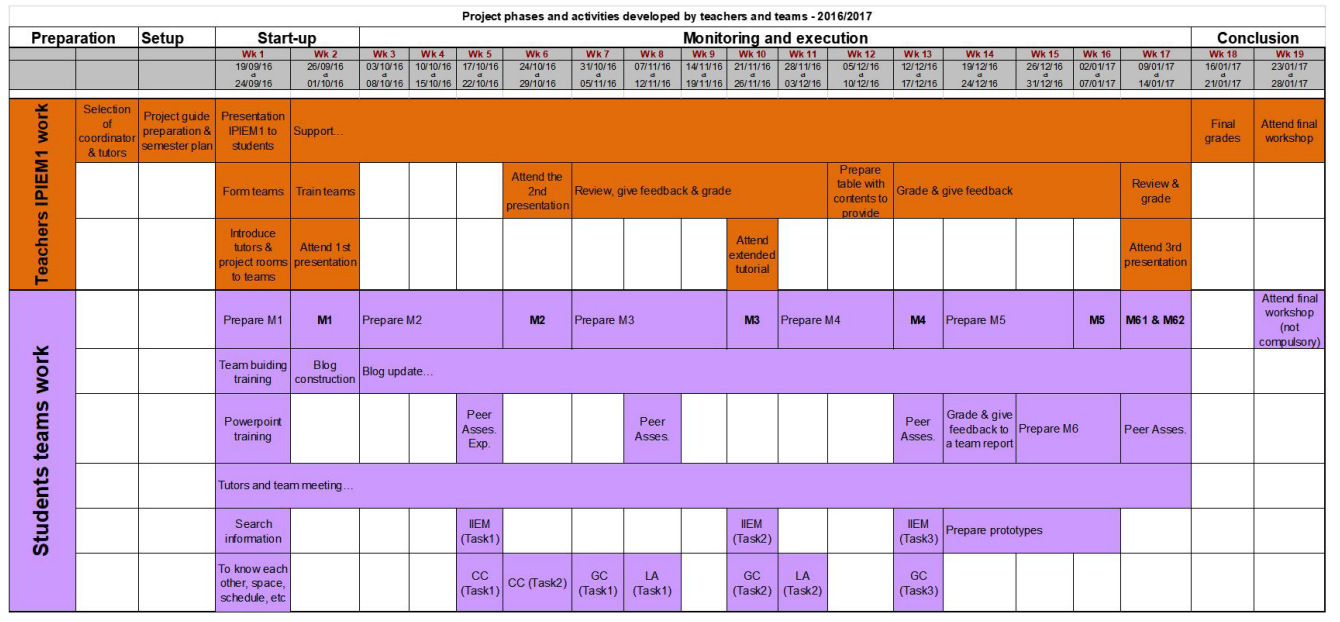

Figure 5. Project phases and activities developed by teachers and project 'teams.

An effort has been done to reduce the workload of teachers and students. In 2009 a study showed that a total of 569 man-hours was demanded to run a PBL in IEM1 (Alves et al., 2009). Since then, some activities were reduced (e.g. number of meetings). Nevertheless, the PBL is more time-consuming than a traditional semester due to the number of activities and people involved. In the edition of this year, for example, six teachers and two more tutors were involved, while in the previous edition the full number of people involved accounted to 11 people only. Thus, a good knowledge of the process is fundamental and more easily achieved with a stabilized process. 


\subsection{Illustrative example of application of interdisciplinary contents}

Reports, presentations and software applications, represent the most common project deliverables. In addition to those, each team developed prototypes and other digital and physical deliverables aimed at detailing the products, representing the shop floor or make proof-of-concepts. These encompassed a number of contents akin to most of the course units of the semester. Remarkably, the teams exhibited capacity to explore a number of different software tools (not addressed in any of those course units), to develop and represent some of the concepts taught on some of the course units. They also made diligences in labs or distinct departments (e.g. Polymers Dpt.) that had no link to the IPIEM in order to fully understand the nature of the processes and acquire technological know-how.

As an example, Figure 6 illustrates a number of concepts and prototypes that Team 3 (who named their company as WooChair) has developed (most of them by their own initiative), to represent their product, the respective production system, and other aspects of their project. A similar analysis could have been conducted on any of the other teams, predictably with similar results.

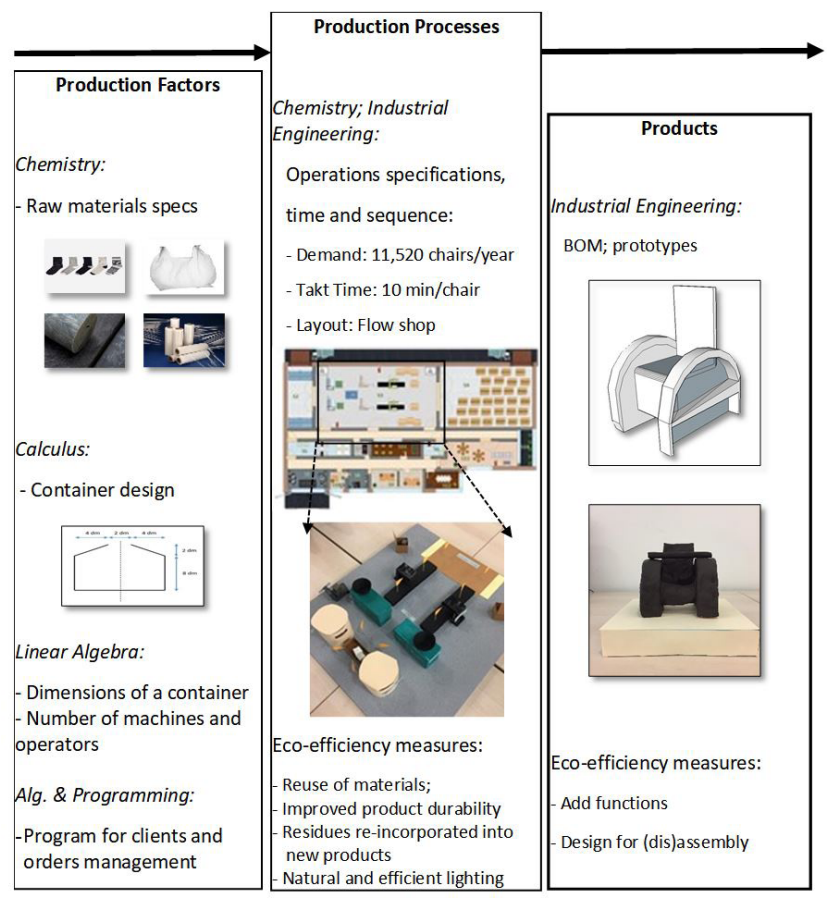

Figure 6. Production system of the Team 3 (WooChair company).

As show by Figure 6, the project allows to pursuit of the best product and the best production system design. This will be one of the main functions of a future Industrial Engineer, as defined by the American Institute of Industrial Engineering in 1960's:

Industrial Engineering is concerned with the design, improvement, and installation of integrated systems of people, materials, equipment, information and energy. It draws upon specialized knowledge and skill in the mathematical, physical, and social sciences, together with the principles and methods of engineering analysis and design to specify, predict, and evaluate the results to be obtained from such systems. (Martin-Vega, 2004, p. 1.11).

\section{STEM contents integration in the projects deliverables: analysis, results and discussion}

This section presents the analysis, results and discussion of the teachers and students' perspectives about integration of STEM courses contents in the project developed by the students. A discussion concluded the section, by presenting some strategies to integrate STEM learning in PBL process, attending to these perspectives. 


\subsection{Teachers' perspectives}

The teacher's perspective provided some insights relating to the integration of the contents of each course in the deliverables, particularly, reports, presentations, individual written test and prototypes. This is also clear in the results of the projects, as shown in the illustrative example of Figure 6 above.

\subsubsection{Introduction to Industrial and Engineering Management}

Relating the integration of IIEM, its contents were thoroughly applied and fully integrated in the project. The required undertakings were related to task 1,2 and 3, which were achieved in the imposed deadlines and all the milestones were accomplished with success (Table 4).

Table 4. IIEM tasks description and achievement results by the teams.

\begin{tabular}{|c|c|}
\hline Tasks description & Task achievement \\
\hline $\begin{array}{l}\text { 1) Project and team management: } \\
\text { a) mission for the project; } \\
\text { b) objectives; } \\
\text { c) deliverables; } \\
\text { d) project plan and the project progress control strategies; } \\
\text { e) motivation \& management conflicts strategies; } \\
\text { f) communication management and the project information repository; } \\
\text { g) other remaining relevant issues for the team. }\end{array}$ & $\begin{array}{l}\text { Template filled with the elements requested; } \\
\text { Organization of project space; } \\
\text { Establish work plan and divide tasks; } \\
\text { Schedule and tasks progress; } \\
\text { Team meetings calendar; } \\
\text { Gantt diagrams, tables and motivation slogan; } \\
\text { Colored post-its with different shapes and contents (Figure 7) (Team } \\
\text { Kanban); } \\
\text { Design a logo for the company/team (Figure 8); } \\
\text { Blog with the project progress. }\end{array}$ \\
\hline $\begin{array}{l}\text { 2) Specification of the production factors, sequence and details on } \\
\text { the processes, and that of the product itself, along with the flow of } \\
\text { materials, the layout, number of machines and operators, product } \\
\text { demand and key performance indicators (KPI), such as productivity, } \\
\text { WIP, production rate, among others. }\end{array}$ & $\begin{array}{l}\text { Written report with required information and measures calculus } \\
\text { including: } \\
\text { a) Process analysis charts for the products designed; } \\
\text { b) Selection of the type of production system; } \\
\text { c) Layout for the company and production system; } \\
\text { d) Material and people flow. }\end{array}$ \\
\hline $\begin{array}{l}\text { 3) Proposals for lndustrial Ecology such as, proposals for preventing } \\
\text { emission of pollutants, conserving materials, energy and water, by } \\
\text { designing products and processes with full life-cycles in mind. }\end{array}$ & $\begin{array}{l}\text { Written report with proposals. } \\
\text { Filled template with the diagram for eco-design strategies, } \\
\text { encompassing eight dimensions, namely a dimension on new product/ } \\
\text { service concepts. }\end{array}$ \\
\hline
\end{tabular}
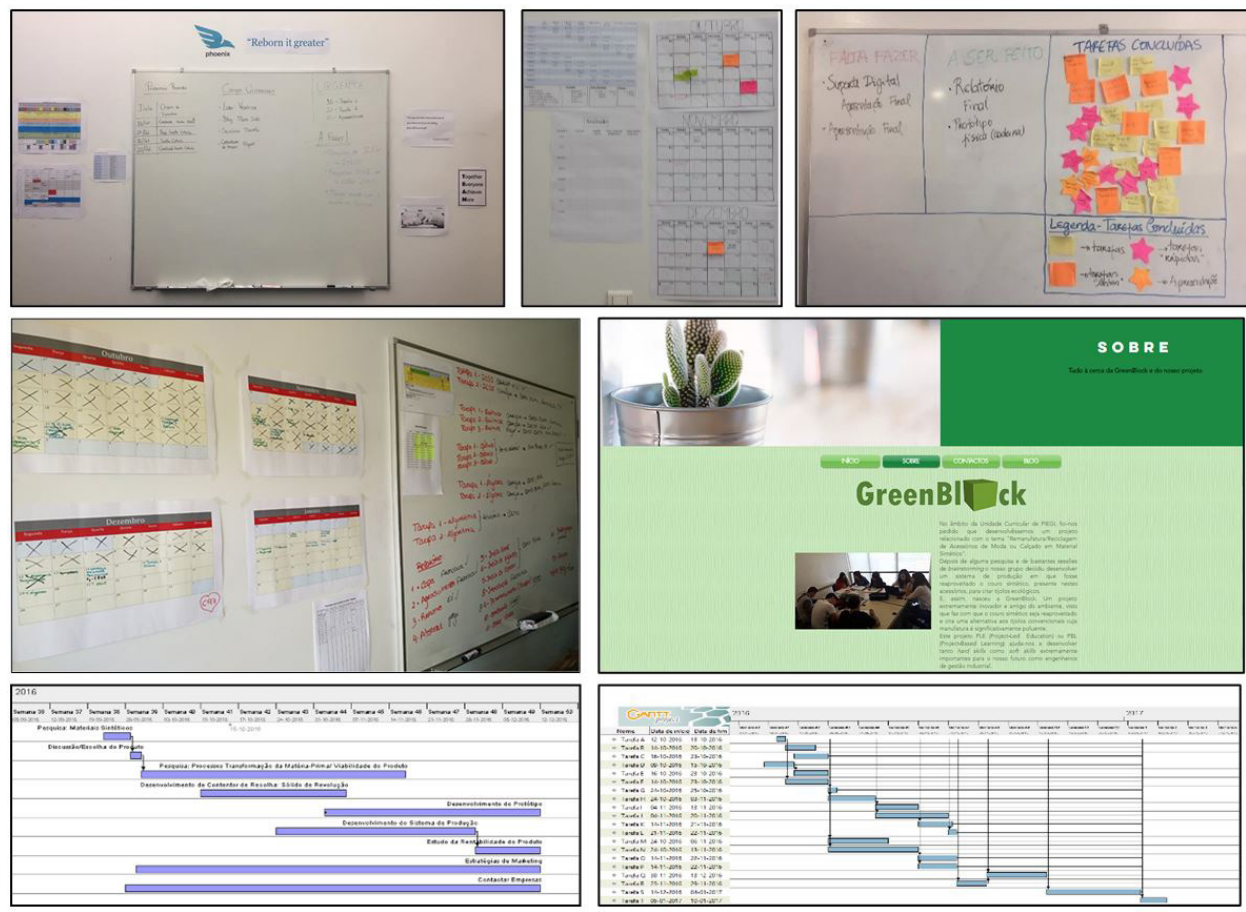

Figure 7. Illustrative pictures of the project room walls, along with Gantt diagrams representing project activities and blogs aspects. 


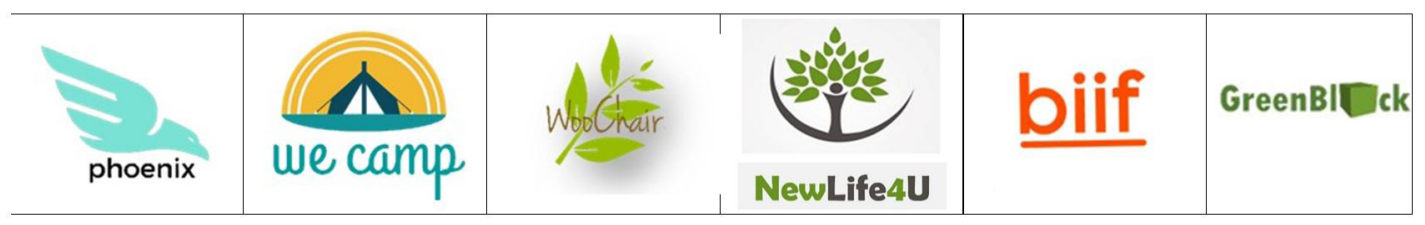

Figure 8. Logos adopted by each team.

In general terms, all students (with minor exceptions) seemed motivated in performing such tasks. Similar reports on undertakings enthusiasm was also verified by Frank et al. (2003) and Berry et al. (2012).

They also designed a Logo and gave a name to "their" company, explaining its meaning. Figure 8 shows the Logos and the chosen business name, for each one of the six teams.

The tasks contents were integrated in the preliminary and final reports of the project and some of its findings were presented as well on the final presentation. Additionally, they developed prototypes of the production system and of the products (not compulsory) that were presented on the final presentation. In spite of the effort in giving feedback to each team, one or two teams seemed to ignore the feedback. Teachers interpreted this more as due to the workload than on purposely ignoring it.

Furthermore, one of the questions of the individual written test on the project, was about the contribution of each course unit to the design of the production system. Almost all the students obtained a very good grade on that item, since they knew exactly what was the specific contribution of IIEM to their particular project.

\subsubsection{General chemistry}

Table 5 presents the tasks description and achievement results by the teams for General Chemistry. In GC, students performed tasks 1 and 2 adequately. Task 3 proved to be especially difficult for students.

Table 5. GC tasks description and achievement results by the teams.

\section{Tasks description}

1) ldentify the name and structure of the polymer (s) to be used in remanufacturing. Describe and explain the structure of the polymer (s) taking into account its (their) chemical constitution.

2) Explain the physical properties of the polymer based on its structure.

3) Discuss the free energy variation associated with a production process to be implemented in the proposed production system in the IPIEM1 and justify the option for the process considering the energy savings.

\section{Task achievement}

Polymer to be used in remanufacturing identified; Chemical structure described;

Some examples of the raw-materials selected by one team are in Figure 6 above.

In the association between structure and physical properties of the polymer, some students showed some difficulties but after the tutorials, the doubts disappeared.

Almost all groups were able to correctly apply the concepts of thermodynamics to a production process described in the report but did not use thermodynamics and equilibrium concepts to optimize production processes even after the tutorials.

Regarding the incorporation of GC contents in the IPIEM1 reports, the existence of tasks with deadlines proved to be very effective since all the groups integrated the contents within the expected deadlines.

Students often complain about time in finding reference papers to meet the objectives of the course proposed in the guide of the project. The introduction of tasks in GC course, related to the objectives proposed in the project, allowed students to use part of the time of independent work of GC to produce contents for the project report. This strategy resulted in a more balanced independent work among the courses and also contributed to a more efficient integration of GC in the IPIEM1.

The GC test about the project was intended to evaluate the degree of knowledge that each one of the elements of each group had about the contents in the project, as in the tutorials that the teacher promoted it was noted that only two elements of each group were deeply involved in the search for information to solve the tasks. And with the test, all students have to know the contents used.

The test results showed that most of the students (80\%) knew the GC contents used for the development of the project and how they had been incorporated, 17\% showed a medium level of knowledge and only 4\% revealed that they did not know the contents or the way they had been used. These results show that although only some members of the group performed the tasks, most of the elements had adequate knowledge about the important issues. 
A significant number of students considered important the existence of GC tasks in order to develop the project. However, they do not agree that the evaluation of the tasks is one of the assessment components of the course. This perception seems to indicate that the students did not realize that the tasks were an activity and an assessment component in the course. In addition, these activities could, or could not, be applied in project solving.

\subsubsection{Algorithms and programming}

Considering the relatively large size of each project team, and assuming that the teams managed to achieve a good task assignment distribution among team members, the AP requirements for the projects were quite reasonable. Nevertheless, given the fact that just a few months earlier these students weren't supposed to possess even the most basic computer programming concepts, the challenge, although adequate for the students' profiles, resulted quite demanding. Table 6 presents the tasks description and achievement results by the teams.

Table 6. AP tasks description and achievement results by the teams.

\begin{tabular}{|c|c|}
\hline Tasks description & Task achievement \\
\hline 1) Define data records (Matlab structs) for business entities. & $\begin{array}{l}\text { Data records as requested for: workers, machines, products, } \\
\text { raw-materials, suppliers, customers, etc. }\end{array}$ \\
\hline 2) Implement some of the business processes in Matlab scripts. & $\begin{array}{l}\text { Use of arrays of the structs for adding, removing, searching, sorting and } \\
\text { listing data records. }\end{array}$ \\
\hline $\begin{array}{l}\text { 3) Create a menu-driven main program in Matlab that allows a user to } \\
\text { choose which of the scripts created in task } 2 \text { to execute. }\end{array}$ & $\begin{array}{l}\text { Computer programs with quality, complexity and size delivered by } \\
\text { the teams ranged from very small to long (one of the programs was } \\
\text { composed of } 102 \text { modules!) }\end{array}$ \\
\hline 4) Add to the programs data persistence capabilities, using Matlab .mat files. & $\begin{array}{l}\text { Being a simple solution for data persistence, .mat files were used by all } \\
\text { the teams, with complexity ranging from very basic to some interesting } \\
\text { solutions. }\end{array}$ \\
\hline
\end{tabular}

The computer programs, as referred in the Table 7 , task 3 , were relatively sophisticated programming techniques and of algorithmic complexity among the teams. The main identified reason for that disparity resided on whether the team benefited from having at least one enthusiastic member in computer programming or not. The second important reason consisted on the degree of fulfilment of the requirements. As a matter of fact, it was observed that while some teams assigned a greater number of active members in the AP project component, others did not. However, given the diversity of knowledge areas (courses) that the projects were required to take account of, and depending on the different personal motivations of the team members towards each of them, it is understandable that, the spending of effort, applied by each team, to each of those knowledge areas, could be somewhat unbalanced.

Table 7. Calculus tasks description and achievement results by the teams.

\section{Tasks description}

Task achievement

1) What is a solid of revolution?; What is a surface of revolution?; Examples of solids and surfaces of revolution and an explanation of how they are construct.

2) Choose an original form for the final product. The object should be, preferentially, a solid of revolution.

Written report with the answers to the questions requested

Team 1 defined a little object with the form of a heart;

Team 2 defined a tent with a form of a round castle;

Team 4 constructed a container with the form of a lipstick;

Team 5 designed a round puff for pets;

Teams 3 and 6 defined a container (see Figure 6 above) and a crusher machine, respectively.

All teams, except Team 1, defined well the necessary plane curves to

3) Calculate the objects' dimension: volume and surface area: introduce the needed curves to construct the solid and their analytic equations; calculate the volume and the surface area of the solid using definite integrals.

construct the desired objects. It seemed that Team 1 gave extreme importance to the originality of the form neglecting its analytic construction. All of them defined well the necessary integrals to calculate the area and the volume of the objects.

From the students' resulting preparation perspective the AP teacher's opinion is that the participation of this course in the IPIEM 1 contributes to introduce them to the notion that an industrial company does not have to deal only with production processes (of physical products) but has, as any business, to manage informational processes (more commonly named "business processes") which deal with information, rather than physical products. 
The students also end-up realizing that these two kinds of processes are highly interrelated and interdependent. The AP teacher strongly believes that this learning outcome strengthens the students' probabilities for, in their future professional careers, being more able to assume higher hierarchical responsibilities in industrial businesses' management. This is aligned with the literature (LaForce et al., 2017).

From the perspective of the benefits that the AP receives for its participation in the IPIEM1, a positive evaluation is also observed. On one hand, there are obvious synergies in motivation, felt by not only the teachers, but also by the students, in realizing that the effort dedicated to each of the courses (AP and the IPIEM1) contributes to learning outcomes that are greater than the sum of the parts.

\subsubsection{Calculus}

All the six students' teams achieved the required tasks of Calculus, Table 7 shows the tasks and their results. Task 1 and 2 were delivered on time and they were well carried out.

Concerning the last and most important Calculus task, the majority invested on the originality of the solid of revolution, as showed in Table 7. Half of the teams didn't choose the final product with the form of a solid of revolution but they created necessary objects to their production system using solids of revolution (Teams 3, 4 and 6).

As expected, some teams had difficulties to calculate some of the obtained integrals. Many of them were impossible to calculate using only analytic methods. So, they could see a difference from the given and obtained integrals in the Calculus classroom exercises and problems. At this point, they asked for help and the teacher advised them to use calculus software. They could see the information given in classes is not enough to achieve their goals.

The teams had to search for other sources of information outside the classes to obtain definition and examples of solids and surfaces of revolution. But, most of the teams used only web contents, rather than more scientific papers. This reinforces the idea that PBL is an active process of investigation (Kolmos, 1996).

In many cases, the mathematical language was not precise. They have many difficulties on writing a text using math formulas and notation. This is due to the fact that students are not used to write math reports.

\subsubsection{Linear algebra}

In general, the students' performance in LA applied to the project was very good. All teams finished in time the tasks, met all deadlines and applied the contents correctly and in an interesting way to the project. Setting deadlines for delivering the tasks proved to be useful for the students in order to work continuously on the project and to present their work correctly in a written form for the report.

The project support lessons, held at the beginning of the semester, were important for teaching some specific LA contents and for the students to deepen their knowledge about the possible application of these contents to the project. The remaining support lessons were also important for the students to discuss their work with the teacher and to obtain feedback about the delivered tasks. This was a mean of improving their work and preparing their work in an oral form for the presentation. However, not all students attended these lessons. This can be explained by the fact that not all team members were involved in working on the LA tasks. Usually, each team assigns each course task to one or two of its members.

The result of the successful application of the LA course contents, listed in Figure 3, in the project by two LA tasks can be confirmed in the example of production system of one team, as presented in Figure 6, above. Teams used these contents to determine production factors number or dimension. Table 8 presents the tasks description and achievement reached by the students.

Concerning the reports, in general, the tasks were adequately described and introduced in the context of the project and the text was well written. A major difficulty revealed to be the correct writing of scientific language, in particular, of mathematical language. Students had difficulties in presenting rigorously and correctly mathematical expressions and notations and to combine written text with calculations. Another problem was that, although each team received individual feedback about the first report, including written comments and corrections, not all corrections were taken into account.

The average grade of the final written project test was approximately $70 \%$ in LA, indicating that, although there was a distribution of specific course tasks in the team, at the end, in average, the students made the effort to study the LA contents and to be well informed about the specific application of these contents to their project. 
Table 8. LA tasks description and achievement results by the teams.

\begin{tabular}{|c|c|}
\hline Tasks description & Task achievement \\
\hline $\begin{array}{l}\text { 1) Apply the concepts of matrices and } \\
\text { determinants to solve an optimization } \\
\text { problem }\end{array}$ & $\begin{array}{l}\text { Determination of the dimensions of: a storage/collection/solvent container or a store, maximizing its } \\
\text { volume given its surface area or minimizing its surface area for a given volume; a brick, maximizing } \\
\text { its volume, given the sum of the edges and its height. }\end{array}$ \\
\hline $\begin{array}{l}\text { 2) ldentify and analyses a system of linear } \\
\text { equations in the project and solve it using } \\
\text { Gaussian elimination or Gauss-Jordan } \\
\text { elimination }\end{array}$ & $\begin{array}{l}\text { Calculate the number of different boxes needed to transport the final products (team 1); the salaries } \\
\text { of the employees in the enterprise (team 2); the number of different workers needed for different } \\
\text { machines in the production system (team3); the number of different vans needed to transport the } \\
\text { final products (team 4, team 5); quantities of raw materials needed to produce a given number of } \\
\text { final products (team 6). }\end{array}$ \\
\hline
\end{tabular}

\subsection{Students' perspectives}

The students perspectives were collected through a questionnaire, as said in section 3, answered at the end of semester after obtained the final grade in the IPIEM1 course. For the research described in this paper, only 14 closed questions and three open-ended questions were used in the analysis, since they were in line with the main objective and better respond to the last research question (Table 9).

Table 9. List of 14 questions used in the analyses and discussion regarding students' perceptions on PBL and descriptive statistics.

\begin{tabular}{|c|c|c|c|c|c|c|c|}
\hline \multirow{2}{*}{ Section } & \multirow{2}{*}{ Code } & \multirow{2}{*}{ Question } & \multicolumn{5}{|c|}{ Descriptive statistics } \\
\hline & & & $\mathrm{m}$ & M & s.d. & $\max$ & $\min$ \\
\hline \multirow{3}{*}{$\begin{array}{l}\text { 1. Project "Remanufacture } \\
\text { of fashion accessories } \\
\text { or footwear made of } \\
\text { synthetic material" }\end{array}$} & Q4 & $\begin{array}{l}\text { For this semester courses' learning, } 1 \text { consider that the proposed } \\
\text { project was adequate }\end{array}$ & 3.8 & 4 & .73 & 5 & 2 \\
\hline & Q5 & $\begin{array}{l}\text { The articulation between the semester's courses was well achieved } \\
\text { with the project }\end{array}$ & 3.7 & 4 & 1.03 & 5 & 2 \\
\hline & Q6 & 1 am proud of the project that my group has developed & 4.6 & 5 & .69 & 5 & 2 \\
\hline \multirow{2}{*}{$\begin{array}{l}\text { 11. Learning and } \\
\text { developed Skills }\end{array}$} & Q8 & $\begin{array}{l}\text { The project allowed me to better understand the relevance of } \\
\text { courses' contents }\end{array}$ & 4.2 & 4 & .82 & 5 & 2 \\
\hline & Q9 & $\begin{array}{l}\text { Through the project, it was possible to see the application of the } \\
\text { contents in real situations }\end{array}$ & 4.3 & 4 & .80 & 5 & 2 \\
\hline \multirow[b]{2}{*}{ 111. Teamwork } & Q17 & 1 prefer to work in groups than individually & 3.6 & 3.5 & .94 & 5 & 2 \\
\hline & Q22 & $\begin{array}{l}1 \text { shared the results of my tasks and knowledge with the rest of } \\
\text { the group }\end{array}$ & 4.4 & 5 & .73 & 5 & 2 \\
\hline \multirow{3}{*}{ IV. Teacher role } & Q35 & $\begin{array}{l}\text { The contents taught by the teachers were enough to complete the } \\
\text { project }\end{array}$ & 3.4 & 3 & 1.16 & 5 & 1 \\
\hline & Q36 & $\begin{array}{l}1 \text { found stimulating to have to look for other sources of } \\
\text { information to complement those of the teachers }\end{array}$ & 3.9 & 4 & .92 & 5 & 2 \\
\hline & Q37 & $\begin{array}{l}1 \text { think } 1 \text { perceived how courses were integrated to design the } \\
\text { production system }\end{array}$ & 4.4 & 4 & .67 & 5 & 3 \\
\hline \multirow[t]{2}{*}{$\begin{array}{l}\text { V. PIEGl evaluation } \\
\text { model }\end{array}$} & Q47 & In general, 1 am satisfied with the obtained results & 3.7 & 4 & .98 & 5 & 2 \\
\hline & Q51 & Overall, 1 considered PBL well organized & 3.8 & 4 & .79 & 5 & 2 \\
\hline \multirow[t]{2}{*}{$\begin{array}{l}\text { V1. PBL as teaching/ } \\
\text { learning methodology }\end{array}$} & Q55 & $\begin{array}{l}\text { PBL requires excessive effort when compared to any other } \\
\text { semester's course }\end{array}$ & 4.6 & 5 & .72 & 5 & 2 \\
\hline & Q56 & 1 believe, however, that this effort is offset by the skills acquired & 4.0 & 4 & .87 & 5 & 2 \\
\hline
\end{tabular}

$\mathrm{m}=$ mean; $\mathrm{M}=$ median; s.d. = standard deviation; max: maximum; $\min =$ minimum.

The students' perspectives are explained in two main parts. The first part analyses the answers distribution of the direct questions related with the integration of course contents. The second part analyses the answers given to the open-ended questions. Tables and graphs will be used to summarize the data obtained.

\subsubsection{General beliefs regarding PBL}

The distributions of the students' answers to the questions Q6, Q17, Q22, Q47, Q51, Q55 and Q56 (Table 1, above), related with the general beliefs regarding PBL evaluation as a learning methodology and the work developed during the semester, are illustrated in Figure 9. The summary of the descriptive statistics is in Table 9. In average, and for the questions in analysis, the students' answers show a positive agreement (means higher than 3).

It is interesting to point out that the vast majority of the students feel proud in having developed a good work in groups (32\% agree and 62\% strongly agree). However, when asked about their satisfaction in working in a group, the students' responses divided between disagree (13\%) and strongly agree (17\%). The students 


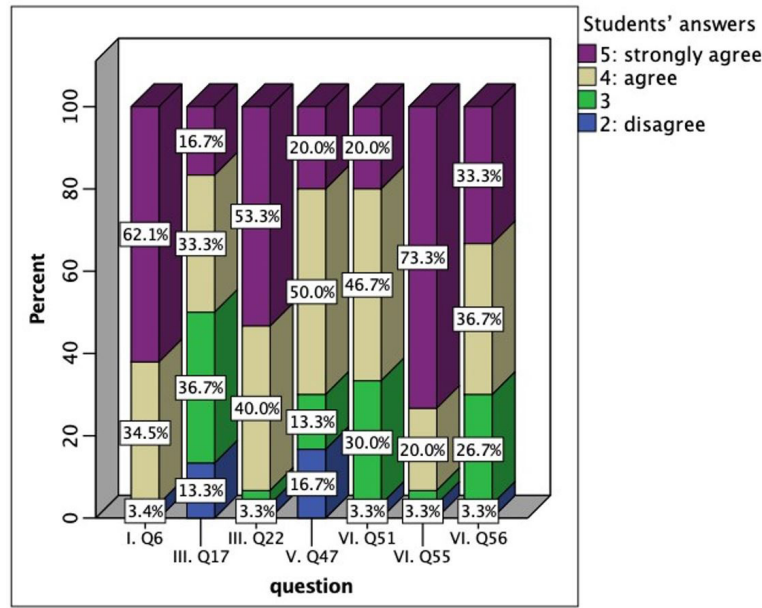

Figure 9. Students' answers distribution for the questions related with general beliefs regarding PBL.

have shown that they have shared their knowhow and worked together in the development of the project (40\% agree and 53\% strongly agree).

Despite the satisfaction expressed by the majority of students regarding the results obtained ( $50 \%$ agree and $20 \%$ strongly agree) and that the PBL approach is well organized (47\% agree and 20\% strongly agree), they consider that PBL requires excessive efforts when compared to any other course, Q55, (20\% agree and 73\% strongly agree). At the same time, the students believe that this effort has been greatly rewarded by the skills and knowledge gained (37\% agree and 33\% strongly agree). In average, Q55, achieved the highest results (mean=4.6).

These results did not surprise the authors, given that the students always complain about the excessive work, but they normally also recognize that it is worth it. This is also in line with the findings made in earlier studies, where students' perceptions of workload were identified, especially when there is a change in the teaching method (Alves et al., 2012; Ruiz-Gallardo et al., 2011).

\subsubsection{STEM integration}

The distributions of the student's answers to the questions Q4, Q5, Q8, Q9, Q35, Q36 and Q37 are illustrated in Figure 10. These are mainly related with the perception about the STEM integration through the proposed project, the articulation of the courses and their relevance, their contents application in real situations, among others. Particularly, Q37 is focused on the understanding of the students about how courses were integrated to design the production system. The summary of the descriptive statistics is presented in Table 9, above.

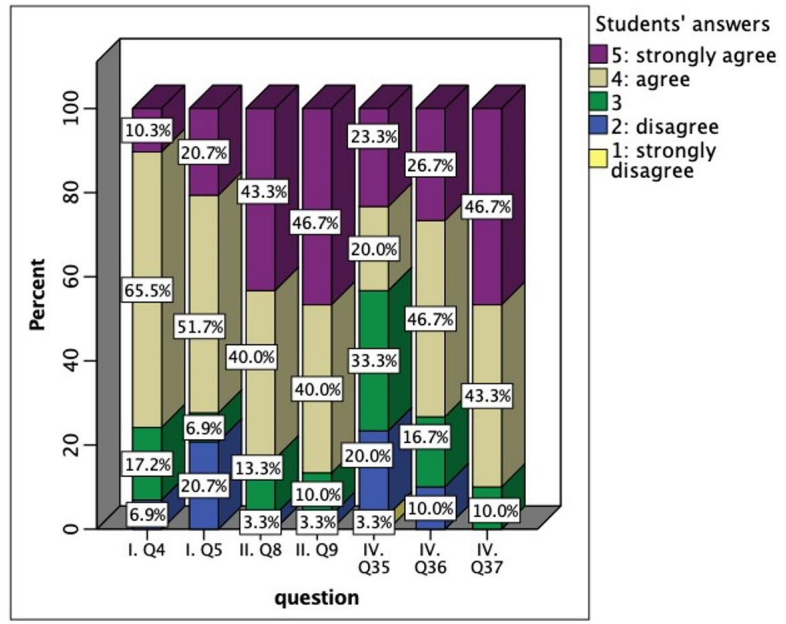

Figure 10. Students' answers distribution for the questions regarding STEM integration. 
A large majority of students evaluated positively the questions under analysis with percentages above the $50 \%$ for agree and strongly agree ( 4 and 5 ). The exception was question 35 (the contents taught by the teachers were enough to complete the project) where the results were scattered between 1 and 5 (strongly disagree and strongly agree, respectively), where the majority of the students (56.6\%) strongly disagree or have a neutral opinion ( 1 to 3). This question corresponds to the lowest mean obtained (mean=3.4, Table 1). On the other hand, this result can be regarded as fundamentally positive, because it encouraged students to seek for alternative sources of knowledge. This was required in order to fulfill the task regarding the development of the project. PBL accomplish this mission force students to "pull" what they need to learn, independently of the source and is aligned with literature (Kolmos, 1996).

The majority of students agree and strongly agree that the project developed was adequate for the learning of the courses, Q4 (66\% and 10\%, respectively) and perceived the articulation between them, Q5 (52\% and 21\%).

The most important question in the context of this paper, Q37, shown that 47\% of students gave the highest score, helping to answer the third research question. Based on their positive answers, we can infer that they perceive how the courses are integrated to design the production system. The example from section 4.3, Figure 6, validates this answer.

\subsubsection{PBL strengths and weaknesses}

In the questionnaire, open-ended questions were issued regarding the main strengths and weaknesses of PBL as a learning methodology in students perspectives. The most frequent words mentioned by the students, to identify the strengths of having participated in the PBL project, were "skills", "development", "better", among others. This is illustrated by a word cloud in Figure 11a (the more frequent the word is used, the larger and bolder is displayed (Souza et al., 2016).
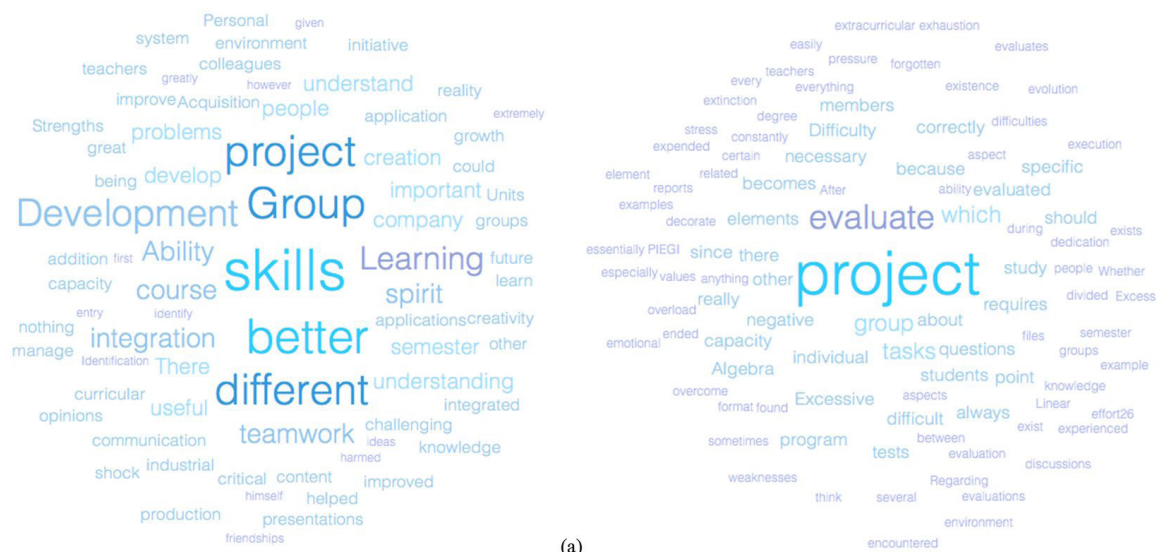

(a)

Figure 11. Word cloud of the more frequent students' words for (a) strengths and (b) weaknesses.

Concerning the weaknesses, students point out the "project" itself together with words like "evaluate", "difficult/difficulties/difficulty", "task" among others words (Figure 11b). In summary, students' reinforce the development of technical skills and soft skills and a better understanding of the complexity of the company's production system as strengths of to be part of the PBL project. In spite of 37\% of the respondents answered "I'm not sure", regarding the preference for working in groups as opposed to individually, the word "teamwork" is a highlighted word.

On the negative side of the PBL project, the students identified as a weakness the large amount of work/assignments to be delivered in the short term. Nevertheless, in the end, most students recognized that these negative aspects turn into positive ones:

Not everything is a sea of roses, but in the end, the sentiment is mutual: pride, satisfaction and fulfillment.

But in the end, we managed to overcome everything successfully and looking back we found that it was all that made us grow. 
Several proposals for changes and improvements were identified by the students. As an example being "to decrease the weight of the individual test in the final evaluation, or not consider this component". This is in fact an issue that requires further reflection to be made subsequently. Somehow, this meets literature' findings, which point out that reduction on the number of assignments and their location within the semester, are two aspects that could reduce the workload (Ruiz-Gallardo et al., 2011).

\subsection{Strategies discussion}

Attending to the results above, it is possible to advise some strategies to integrated STEM in the PBL process. Such strategies included the development of tasks by the students required to be delivered in specific moments during the semester. These tasks took distinct shades in perspective of each course, regarding their integration on the final solution. Some examples are the production system prototype, other physical or digital prototypes (products, containers, software programs, etc.) and other features (i.e. production factors) that are needed to design a production system, in order to manufacture a product, as shown in the example provided in Figure 6.

Another important strategy was to delegate on students the assessment of the reports from other teams. They have conducted that task responsibly, and they acknowledged the difficulty in making assessments of others work. This has revealed a worthwhile strategy given that the students have learned to assess the work of others in a grounded way. Another positive outcome for the students was the raised awareness that the contents taught in each course are not enough to complete the project. In this way, the project could be viewed as an extension of the curriculum.

Considering the strengths and weaknesses of the PBL strategies pointed out by the students, it can be concluded that an adequate combination of strategies enhances the integration of contents. A puzzled outcome is that weaknesses and strengths of different strategies can compensate each other. For example, the assessment model implies a high workload, which is a weakness from students' perspective. However, the same assessment model has the effect of making a faster step-by-step progress, since the teams receive continuous feedback on the various tasks.

The tasks have well defined deadlines and are effective for integrating the course contents within those expected deadlines, which is pointed out by some teachers as a strength. In spite of the apparent excessive workload, the students coherently agreed and recognized that IPIEM1 is a course like no others and it is more than the sum of parts.

Another example of weakness-strength compensation by strategies is the fact that only some team members normally work on each task, where instead teamwork is expected, is seen by the teachers as a weakness point, since this could imply a lack of overall knowledge about the STEM applications. However, the strategy of having a final written test about the integration of all contents compensates the weakness, in the sense that in the end all team members studied the course contents and proved to be predominantly well knowledgeable on the STEM integration in the project.

\section{Conclusions}

This paper concern was to present, analyze and discuss the contents integration of STEM courses in first year, first semester of an IEM program in the context of a PBL methodology. In spite of the fourteen successful editions previous held, the teachers are always seeking for improvements. The recognition that STEM contents must be integrated within the PBL, stimulates the pursuit of strategies to integrate them effectively, systematized as tasks execution by teams along the project progress and continuous feedback, teams' responsibility in assessing others teams work and assessment instruments to involve all students in the learning.

Teachers' perspective point out a general satisfaction with the way teams used each course knowledge and competences to design the production system and the products. The teachers also agreed that a good knowledge of the PBL process is essential for sustaining and properly running the project. The students' perspectives pointed out to the same positive opinion. Students seemed to know the role of each course in conceiving both the production system and the product designs.

The process of project development promotes competences that none other course by itself promotes, such as critical thinking, communication, collaboration and creativity (4C), as referred in the survey of the American Management Association (2012), among others (e.g. people and conflict management; interpersonal and social skills; complex problem-solving skills) that are considered fundamental for $21^{\text {st }}$ century (United Nations Educational, Scientific and Cultural Organization, 2016). However, there are always space for improvements and 
some pitfalls were detected (e.g. better balance between courses work, individual written test elimination or its weight reduction, training in mathematical writing skills) to be solved in future editions.

\section{Acknowledgements}

This work has been supported by FCT - Fundação para a Ciência e Tecnologia within the Project Scope: UID/CEC/00319/2019.

\section{References}

Alves, A. C., \& Leão, C. P. (2015). Action, practice and research in project based learning in an industrial engineering and management program. In Proceedings of the ASME 2015 International Mechanical Engineering Congress and Exposition (Vol. 5). Houston: ASME. https://doi.org/10.1115/IMECE2015-51438.

Alves, A. C., Moreira, F., Leão, C. L., \& Carvalho, M. A. (2017). Sustainability and circular economy through PBL: engineering students' perceptions. In Proceedings of the Conference Wastes 2017. Porto: Taylor \& Francis.

Alves, A. C., Moreira, F., Lima, R., Sousa, R., Dinis-Carvalho, J., Mesquita, D., Mesquita, D., Fernandes, S. \& Van Hattum-Janssen, N. (2012). Project based learning in first year, first semester of industrial engineering and management: some results. In Proceedings of the 5th ASME International Mechanical Engineering Congress and Exposition (IMECE) (pp. 111-120). Houston: ASME. https:// doi.org/10.1115/IMECE2012-89046.

Alves, A. C., Moreira, F., Sousa, R., \& Lima, R. M. (2009). Teachers' workload in a project-led engineering education approach. In Proceedings of the 14th International Symposium on Innovation and Assessment of Engineering Curricula. Braga: Universidade do Minho. Retrieved in 2018, January 21, from http://hdl.handle.net/1822/19133

Alves, A. C., Sousa, R. M., Fernandes, S., Cardoso, E., Carvalho, M. A., Figueiredo, J., \& Pereira, R. M. S. (2016b). Teacher's experiences in PBL: implications for practice. European Journal of Engineering Education, 41(2), 123-141. http://dx.doi.org/10.1080/030437 97.2015.1023782.

Alves, A., Sousa, R., Moreira, F., Carvalho, M. A., Cardoso, E., Pimenta, P., Malheiro, T., Brito, 1., Fernandes, S., \& Mesquita, D. (2016a). Managing PBL difficulties in an industrial engineering and management program. Journal of Industrial Engineering and Management, 9(3), 586. http://dx.doi.org/10.3926/jiem.1816.

American Management Association - AMA. (2012). Critical skills survey. Retrieved in 2018, January 21, from http://www.amanet.org/

Bell, D. (2016). The reality of STEM education, design and technology teachers' perceptions: a phenomenographic study. International Journal of Technology and Design Education, 26(1), 61-79. http://dx.doi.org/10.1007/s10798-015-9300-9.

Berry, M., Chalmers, C., \& Chandra, V. (2012). STEM futures and practice, can we teach stem in a more meaningful and integrated way? In STEM 2012: Instructional Innovations and Interdisciplinary Research in STEM Education Conference (pp. 225-240). United Kingdom. Retrieved in 2018, January 21, from http://hdl.handle.net/10072/52346\%0D

Bonwell, C. C., \& Eison, J. A. (1991). Active learning: creating excitement in the classroom (ASHE-ERIC Higher Education Report). Washington: George Washington University.

Capraro, R. M., Capraro, M. M., \& Morgan, J. R. (2013). STEM project-based learning: an integrated science, technology, engineering, and mathematics approach (2nd ed.). Rotterdam: Sense Publishers. http://dx.doi.org/10.1007/978-94-6209-143-6.

Colombo, C. R., Alves, A. C., Van Hattum-Janssen, N., \& Moreira, F. (2014). Active learning based sustainability education: a case study. In Proceedings of Project Approaches in Engineering Education (PAEE'2014) (pp. ID55.1-9). Portugal: University of Minho. Retrieved in 2018, January 21, from http://repositorium.sdum.uminho.pt/bitstream/1822/30173/1/paee2014_submission_55.pdf

Eguchi, A. (2016). RoboCupJunior for promoting STEM education, 21st century skills, and technological advancement through robotics competition. Robotics and Autonomous Systems, 75, 692-699. http://dx.doi.org/10.1016/j.robot.2015.05.013.

European Commission. Eurydice. (2010). Focus on higher education in Europe 2010: the impact of the Bologna process. Brussels.

European Commission. (2013). High level group on the modernisation of higher education: report to the european commission on improving the quality of teaching and learning in Europe's higher education institutions. Brussels. http://dx.doi.org/10.2766/42468

Fini, E. H., Awadallah, F., Parast, M. M., \& Abu-Lebdeh, T. (2018). The impact of project-based learning on improving student learning outcomes of sustainability concepts in transportation engineering courses. European Journal of Engineering Education, 43(3), 473488. http://dx.doi.org/10.1080/03043797.2017.1393045.

Frank, M., Lavy, 1., \& Elata, D. (2003). Implementing the project-based learning approach in an academic engineering course. International Journal of Technology and Design Education, 13(3), 273-288. http://dx.doi.org/10.1023/A:1026192113732.

Freeman, S., Eddy, S. L., McDonough, M., Smith, M. K., Okoroafor, N., Jordt, H., \& Wenderoth, M. P. (2014). Active learning increases student performance in science, engineering, and mathematics. Proceedings of the National Academy of Sciences of the United States of America, 111(23), 8410-8415. http://dx.doi.org/10.1073/pnas.1319030111. PMid:24821756.

Graaff, E., \& Kolmos, A. (2007). Management of change: implementation of problem-based and project-based learning in engineering. Roterdam: Sense Publishers.

Guerra, A., Ulseth, R., \& Kolmos, A. (2017). PBL in engineering education: international perspectives on curriculum change. Springer. http://dx.doi.org/10.1007/978-94-6300-905-8.

Han, S., Capraro, R., \& Capraro, M. M. (2015). How Science, Technology, Engineering, and Mathematics (STEM) Project-Based Learning (PBL) affects high, middle and low achievers differently: the impact of student factors on achievement. International Journal of Science and Mathematics Education, 13(5), 1089-1113. http://dx.doi.org/10.1007/s10763-014-9526-0.

Han, S., Capraro, R. M., \& Capraro, M. M. (2016). How science, technology, engineering, and mathematics project based learning affects high-need students in the U.S. Learning and Individual Differences, 51, 157-166. http://dx.doi.org/10.1016/j.lindif.2016.08.045. 
Harmer, N. (2014). Project-based learning: literature review. Retrieved in 2018, January 21, from https://www.plymouth.ac.uk/uploads/ production/document/path/2/2733/Literature_review_Project-based_learning.pdf

Heywood, J. (2005). Engineering education: research and development in curriculum and instruction. Hoboken: John Wiley \& Sons. http://dx.doi.org/10.1002/0471744697.

Hsieh, H.-F., \& Shannon, S. E. (2005). Three approaches to qualitative content analysis. Qualitative Health Research, 15(9), $1277-1288$. http://dx.doi.org/10.1177/1049732305276687. PMid:16204405.

Kezar, A., Gehrke, S., \& Bernstein-Sierra, S. (2017). Designing for success in STEM communities of practice: philosophy and personal interactions. The Review of Higher Education, 4O(2), 217-244. http://dx.doi.org/10.1353/rhe.2017.0002.

Knoll, M. (1997). The project method: its vocational education origin and international development. Journal of Industrial Teacher Education, 34(3), 59-80.

Kolmos, A. (1996). Reflections on project work and problem-based learning. European Journal of Engineering Education, $21(2), 141$ 148. http://dx.doi.org/10.1080/03043799608923397.

Laboy-Rush, D. (2011). Integrated STEM Education through Project-Based Learning. learning.com.

LaForce, M., Noble, E., \& Blackwell, C. (2017). Problem-Based Learning (PBL) and student interest in STEM careers: the roles of motivation and ability beliefs. Education in Science, 74), 92. http://dx.doi.org/10.3390/educsci7040092.

Lima, R. M., Carvalho, D., Assunção Flores, M., \& Van Hattum-Janssen, N. (2007). A case study on project led education in engineering: students and teachers perceptions. European Journal of Engineering Education, 32(3), 337-347. http://dx.doi. org/10.1080/03043790701278599.

Lima, R. M., Carvalho, D., Sousa, R. M., Alves, A., Moreira, F., Mesquita, D., \& Fernandes, S. (2012). A project management framework for planning and executing interdisciplinary learning projects in engineering education. In L. C. Campos, E. A. T. Dirani, A. L. Manrique \& N. van Hattum-Janssen (Eds.), Project approaches to learning in engineering education: the practice of teamwork. Sense Publishers. http://dx.doi.org/10.1007/978-94-6091-958-9_5.

Lima, R. M., Dinis-Carvalho, J., Sousa, R. M., Alves, A. C., Moreira, F., Fernandes, S., \& Mesquita, D. (2017). Ten years of project-based learning (PBL) in Industrial Engineering and Management at the University of Minho. In A. Guerra, R. Ulseth \& A. Kolmos (Eds.), $P B L$ in engineering education: international perspectives on curriculum change. Springer.

Lou, S.-J., Chou, Y.-C., Shih, R.-C., \& Chung, C.-C. (2017). A study of creativity in CaC2 Steamship-derived STEM project-based learning. Eurasia Journal of Mathematics, Science and Technology Education, 13(6), 2387-2404. http://dx.doi.org/10.12973/eurasia.2017.01231a.

Martin-Vega, L. A. (2004). The purpose and evolution of industrial engineering. In K. B. Zandin (Ed.), Maynard's industrial engineering handbook. New York: McGraw Hill.

Moreira, F., Mesquita, D., \& van Hattum-Janssen, N. Van. (2011). The importance of the project theme in Project-Based learning: a study of student and teacher perceptions. In Proceedings of the 2011 Project Approaches in Engineering Education (Vol. 53). Lisbon. https://doi.org/10.1017/CB09781107415324.004.

Onwuegbuzie, A. J., \& Leech, N. L. (2006). Linking research questions to mixed methods data analysis procedures. Qualitative Report, 11(3), 474-498.

Pereira, M. A. C., Barreto, M. A. M., \& Pazeti, M. (2017). Application of Project-Based Learning in the first year of an Industrial Engineering Program: lessons learned and challenges. Production, 27spe), e20162238. http://dx.doi.org/10.1590/0103-6513.223816.

Powell, P., \& Weenk, W. (2003). Project-led engineering education (Vol. 53). Cambridge: Cambridge University Press.

Ritz, J. M., \& Fan, S.-C. (2015). STEM and technology education: international state-of-the-art. International Journal of Technology and Design Education, 25(4), 429-451. http://dx.doi.org/10.1007/s10798-014-9290-z.

Ruiz-Gallardo, J.-R., Castaño, S., Gómez-Alday, J. J., \& Valdés, A. (2011). Assessing student workload in problem based learning: relationships among teaching method, student workload and achievement: a case study in natural sciences. Teaching and Teacher Education, 27(3), 619-627. http://dx.doi.org/10.1016/j.tate.2010.11.001.

Santos, P. F., Simon, A. T., Guimarães, G. E., Amorim, M., \& Vieira Junior, M. (2017). Analyzing the competences of production engineering graduates: an industry perspective. Production, 27. http://dx.doi.org/10.1590/0103-6513.005317.

Souza, F. N., Costa, A. P., \& Moreira, A. (2016). webQDA. Retrieved in 2018, January 21, from www.webqda.net

Stohlmann, M., Moore, T. J., \& Roehrig, G. H. (2012). Considerations for teaching integrated STEM education. Journal of Pre-College Engineering Education Research, 2(1), 28-34. http://dx.doi.org/10.5703/1288284314653.

Thomas, B., \& Watters, J. J. (2015). Perspectives on Australian, Indian and Malaysian approaches to STEM education. International Journal of Educational Development, 45, 42-53. http://dx.doi.org/10.1016/j.jjedudev.2015.08.002.

Tseng, K.-H., Chang, C.-C., Lou, S.-J., \& Chen, W.-P. (2013). Attitudes towards science, technology, engineering and mathematics (STEM) in a project-based learning (PjBL) environment. International Journal of Technology and Design Education, 23(1), 87-102. http://dx.doi.org/10.1007/s10798-011-9160-x.

United Nations Educational, Scientific and Cultural Organization - UNESCO. (2010). Engineering: issues, challenges and opportunities for development. Paris: UNESCO.

United Nations Educational, Scientific and Cultural Organization - UNESCO. (2016). Education 2030: incheon declaration and framework for action for the implementation of sustainable development goal 4. Paris: UNESCO. Retrieved in 2018, January 21, from http://uis. unesco.org/sites/default/files/documents/education-2030-incheon-framework-for-action-implementation-of-sdg4-2016-en_2.pdf

Vygotsky, L. S. (1986). Thought and language. Cambridge: MIT Press. 